\title{
ІСТОРИЧНА ПЕРСПЕКТИВА ВИКОРИСТАННЯ МИНУЛОГО ДЛЯ ВИВЧЕННЯ СУЧАСНОСТІ ВЕДЕННЯ БІЗНЕСУ
}

\section{A HISTORICAL PERSPECTIVE OF USING THE PAST TO STUDY THE MODERNITY OF DOING BUSINESS}

\author{
Савченко Ольга Олександрівна \\ старший викладач, кандидат історичних наук \\ Національний університет «Львівська політехніка» \\ ORCID: https://orcid.org/0000-0002-6172-1931
}

\author{
Savchenko Olga \\ Lviv Polytechnic National University
}

\begin{abstract}
Метою статті є дослідження історичної перспективи в розрізі використання минулого досвіду для дослідження та розуміння сучасності ведення бізнесу. Об'єктом дослідження виступають характерні риси та особливості історичного минулого в контексті їх використання для вивчення сучасності. У статті були використані такі методи: загальнонаукові методи (формально-логічний, системний, структурно-функціональний, конкретно-історичний); логічні методи теоретичного аналізу (аналіз, синтез, узагальнення, порівняння, абстракція, аналогія.); технічний аналіз, роз'яснення. Результати дослідження свідчать про те, що кожен окремий етап розвитку бізнесу характеризується унікальним цивілізаційним устроєм, який фрормувався після існування складного та тривалого перехідного періоду. Було з'ясовано, що в історичному ракурсі перехідні періоди являють собою розриви історичного процесу, що фоункціонують як майстерні для деструктивного творчості, де творчість $€$ інструментом руйнування, а руйнування - передумовою для творчості та реконструкції. Було встановлено, що історичний шлях кожної цивілізації закінчується певним перехідним періодом, що є індикатором закінченням одного історичного періоду та початком іншого, при чому кожним період має свої логічні та динамічні особливості та актуальний лише для суспільства окремого часового проміжку.
\end{abstract}

Ключові слова: історична перспектива, сучасність, минуле, глобалізація, історія, бізнес.

Целью статьи является исследование исторической перспективы в разрезе использования прошлого опыта для исследования и понимания современности ведения бизнеса. Объектом исследования выступают характерные черты и особенности исторического прошлого в контексте их использования для изучения современности. В статье были использованы следующие методы: общенаучные методы (формально-логический, системный, структурно-функциональный, конкретно-исторический) логические методы теоретического анализа (анализ, синтез, обобщение, сравнение, абстракция, аналогия.) технический анализ, разъяснения. Результаты исследования свидетельствуют о том, что каждый отдельный этап развития бизнеса характеризуется уникальным цивилизационным устройством, который фрормировался после существования сложного и длительного переходного периода. Было выяснено, что в историческом ракурсе переходные периоды представляют собой разрывы исторического процесса, функционирующих как мастерские для деструктивного творчества, где творчество является инструментом разрушения, а разрушения - предпосылкой для творчества и реконструкции. Было установлено, что исторический путь каждой цивилизации заканчивается определенным переходным периодом, является индикатором окончанием одного исторического периода и началом другого, причем каждым период имеет свои логические и динамические особенности и актуален лишь для общества отдельного периода времени.

Ключевые слова: историческая перспектива, современность, прошлое, глобализация, история, бизнес.

The processes of globalization today are the most powerful transformation of the world, therefore, understanding the importance and consequences of this process is a difficult but necessary task for the modern scientific community. Humanity, despite all fears and doubts about being considered new, must constantly adapt and respond to the challenges of globalization processes, as well as realize and use all the laws of globalization processes to its advantage, determines its strength and vectorial action. If these processes are ignored, people face the risk of living and developing harmoniously, as well as creating a habitable environment for future generations. Awareness of the main opportunities and consequences that arise as a result of globalization processes gives a person a modality to use these opportunities, as well as to influence possible consequences, potentiating or minimizing them, depending 
on the kind of consequences. Taking this into account, today it is especially important to pay attention to the historical origins of these processes in order to fully understand modern processes. The aim of the article is to study the historical perspective in the context of the use of past experience for the study and understanding of the present. The object of the research is the characteristic features and features of the historical past in the context of their use for the study of the present. The following methods were used in the article: general scientific methods (formal-logical, systemic, structural-functional, concrete-historical) logical methods of theoretical analysis (analysis, synthesis, generalization, comparison, abstraction, analogy), technical analysis, explanations. The results of the study indicate that each separate stage of human development is characterized by a unique civilizational structure, which was formed after the existence of a complex and long transitional period. It was found that from a historical perspective, transitional periods represent breaks in the historical process, functioning as workshops for destructive creativity, where creativity is an instrument of destruction, and destruction is a prerequisite for creativity and reconstruction. It was found that the historical path of each civilization ends with a certain transitional period, is an indicator of the end of one historical period and the beginning of another, and each period has its own logical and dynamic characteristics and is relevant only for the society of a particular period of time.

Keywords: historical perspective, modernity, past, globalization, history.

Постановка проблеми. Поняття «історична перспектива» визначається як дослідження об'єкту в контексті аналізування його початкових етапів існування і подальшою еволюцією. Порівнюючи такі поняття як «історична перспектива» та безпосередньо «історія», варто зазначати, що основна відмінність цих термінів полягає в тому, що мета історичної перспективи в тому, щоб через призму минулого, краще зрозуміти основні процеси та закономірності сучасності. До прикладу, дослідження письмових доказів та артефрактів для вивчення періоду депресії $€$ історичним дослідженням, в той час як використання письмових доказів та артефрактів часів депресії для пояснення певних фрактів та явищ сучасності $€$ вже історичною перспективою. Історія надає ресурси для проведення історичної перспективи. I хоча на перший погляд першочерговим кроком у вивченні певних процесів $\epsilon$ вивчення їх історичних передумов їх розвитку та історичного шляху розвитку, історична перспектива часто не береться до уваги під час дослідження. Причиною цього явище $є$ те, що більшість наукових досліджень більше зорієнтовані на прогрес та майбутню перспективу.

Твердження «соціологічне дослідження пройшли значний шлях свого розвитку» передбачає, що сучасний стан останніх в значній мірі відрізняється від аналогічного стану в минулому і $\epsilon$ в рази краще за цього. Та попри те, помилковим буде ідентиорікувати як примітивне, та в той же час використовувати його як ключ до розуміння сучасності. 3 огляду на це, велика кількість соціологів використовують дані про минулий стан об'єкту не лише в контексті дослідження історичного прогресу, а для кращого розуміння сьогоденних подій. Постає питання ролі історичної перспективи в цьому дослідженні та які елементи висновків або теорії можуть називатись трансісторич- ними? Відповіддю на це питання стає перевірка «великої» теорії, яка визначає те, що $€$ універсальним у поведінці людей на противагу тому, що історично у людській поведінці не володіє універсальністю. Але приймаючи той фракт, що у своїй більшості соціальні науки не володіють універсальністю, виникає наступне «усереднене» питання: протягом якого проміжку часу висновки та теорія можуть володіти ознаками універсальності.

Протягом всього XXI століття, у всіх частинах світу суспільні устрої стикались та намагались побороти одну кризу за іншою, при цьому відчуваючи втрату напрямків. Ті технології, які можуть покращити наше повсякденне фрункціонування, на сьогоднішній день розвиваються швидше ніж формується наша здатність їх використовувати. В цьому процесі залучена велика кількість людей, організацій та установ, і часто інтереси всіх цих суб'єктів суперечать одне одному. Внаслідок цього процесу і виникає явище «перехідного періоду» світу, в якому і ідеологічні та світські сили на певний час отримують можливість відігравати першочергову роль в процесі стимуляції змін та значних соціально-економічних трансорормації та відповідним їх наслідкам.

Як зазначають, за останні три десятки років минулого століття ми могли спостерігати і стати свідками так званого «10-ного підвищення обсягів і кількостей електронних засобів зв'язку і десятикратного скорочення особистих контактів». Такого роду зміни відбувалися ще до того як Інтернет як глобальне явище покращився і став частиною нашого життя в повсякденності. Як приклад, можна навести той факт, що соціально-економічні трансформації, які ще колись не так давно могли викликати так звану інфрормаційну революцію, зараз досі активно впливають на сьогоденну реальність та наше сприйняття 
останньої. А з огляду на те, що трансорормаційні сили лише продовжують набирати оберти, на сьогоднішній день вже можна стверджувати що наш світ знаходиться саме в цьому «перехідному періоді», який характеризується швидкими змінами, та в якому всі припущення, які стосувалися старих теорій та моделей, втратили свою актуальність та користь. Ті ідеї і соціальні інститути, які давали змогу покращити систему управління суспільним життя, економічні відносини, визначилися неадекватними в тій чи іншій мірі.

В сучасних умовах розвитку, суспільство зустрічається і встає перед такими проблемами, які попросту не піддаються жодному визначенню. В цей же час, ключові соціальні, економічні та політичні системи в кожному суспільстві стають все більш складними і в значній мірі взаємозалежними. Так чи інакше, глобалізація виходить за рамки економіки і економічних відносин, торгівлі, культури і починає охоплювати все масштабніше і практичну кожний аспект нашого 3 вами життя, роблячи взаємозалежність між системами, організаціями, націями і державами незаперечним фактом життя. I той фракт, що застарілі інструменти проведення аналізу і теорії дуже оперативно перестають працювати, нові ж інструменти поки не прийшли на їхнє місце. Таким чином, порядок дня межує з безладом. Кожен раз, коли суспільство переходить від однієї фрази історичного розвитку до іншої, воно проходить через перехідний період, який характеризується хаосом і втратою напрямки, який триває десятиліття чи століття. Саме тому, сьогодні вкрай важливим є дослідження історичної перспективи використання минулого для подальшого вивчення сучасності і недопущення попередніх помилок.

Аналіз останніх досліджень. Питання вивчення історичної перспективи використання минулого для вивчення сучасності розвитку бізнесу було увагою багатьох науковців, зокрема: Braudel, Brenner, Robinson, Sklair, Wade, Wallerstein та інші.

Метою статті $€$ висвітлення історичної перспективи використання минулого для вивчення сучасності розвитку бізнесу.

Об'єктом дослідження виступає особливості історичного минулого в контексті їх використання для вивчення сучасності розвитку бізнесу.

У даній статті були використані наступні методи: загальнонаукові методи (формальнологічний, системний, структурно-срункціональний, конкретно-історичний); логічні методи теоретичного аналізу (аналіз, синтез, узагальнення, порівняння, абстракція, аналогія); технічний аналіз, роз'яснення.

Виклад основного матеріалу дослідження. 3 розвитком сільського господарства близько 10000 років тому економічні основи життя почали змінюватися, в результаті чого племінне суспільство вступило в перехідний період, який характеризується глибокими соціальними і економічними перетвореннями. "Одомашнення рослин і тварин означало набагато більше їжі i, отже, набагато більш щільне населення. Виникаючі в результаті надлишки їжі і (в деяких районах) засоби транспортування цих надлишків, засновані на тварин, були передумовою для розвитку осілих, політично централізованих, соціально стратифікована, економічно складні, технологічно інноваційні суспільства». Однак після того, як сільське господарство стало способом життя і повністю розвинулась його культура, нове суспільство почало дуже повільно змінюватися. Соціально-економічні сили змін були або сильно обмежені, або ще не народилися. Найбільш значною зміною в останні століття сільськогосподарської ери було розширення торгівлі, включення купецької життя в економічне життя суспільства і поява держав і імперій. Товарна продукція згодом перетворилася в зростаючу економічну активність, що призвело до розширення ссрери послуг і поступового розвитку соціальних і політичних і Зміна, які поступово трансорормують всі аспекти життя.

Розвиток сільського господарства викликало найважливішу революцію в історії людства. Він змінив минуле життя людей, змінивши ставлення людей один 3 одним і 3 навколишнім їх середовищем. Сільськогосподарська революція породила нову цивілізацію зі своєю власною культурою, економікою і соціальною і політичною організацією. «Перехід від полювання і збирання до сільського господарства означав щось більше, ніж проста зміна способу життя; він був повна зміна соціальної і культурної тканини життя ». Це «означало також зміна розуму». У результаті цих подій первісна племінна цивілізація і ії культурні моделі застаріли і набула широкого вжитку відносно менш цивілізованими. Отже, історія полювання і збирання закінчилася 3 настанням сільськогосподарської ери, і зародилася нова цивілізація. Хоча племінна історія продовжувала існувати ще тисячі років, під державною надбудовою вони втратили більшу частину своєї землі, свободи і імпульсу. 
Сільськогосподарська цивілізація і державна надбудова змусили племінне суспільство прийняти круговий рух в рамках все більш тісного і обмеженого фрізичного i політичного простору. До п'ятнадцятого століття жоден центр цивілізації або держави не зазнав досить змін, щоб відрізнятися від інших центрів. Пол Кеннеді стверджує, що кожен з великих центрів світової цивілізації в кінці 15 століття знаходився приблизно на однаковій стадії розвитку; всі великі народи минулого жили в епоху сільського господарства і мали однакову культуру і однаковий рівень життя [1-2].

Економічна база, соціальні та економічні структури, політична організація і стан технологій всюди були однаковими. Через це «світ утворив єдину, хоча й велику, соціальну систему, яка працює набагато повільніше, ніж та, до якої ми звикли».

Але приблизно в середині п'ятнадцятого століття зміна економічних умов і соціокультурних аспектів життя почав прискорюватися в деяких європейських регіонах. Торгівля, яка на той час стала провідним видом економічної діяльності, призвела до змін і проклала шлях для подальших соціально-економічних перетворень. Інші події, які відбулися згодом і брали участь в просуванні змін і допомоги в прискоренні їх темпів, включали наступне: істотне поліпшення навігаційних інструментів і карт, будівництво кращих доріг і кораблів, виробництво більш потужної зброї, посилення безпеки, зростаюча конкуренція між основними Європейські міста та держави , розвиток книгодрукування і відкриття європейцями того, що було для них новим світом. Згодом виробнича та інша комерційна діяльність розширилася, а наукові, технологічні та фрілософрські дослідження розмножилися. Однак без релігійних ресормаційних воєн, які тривали близько 80 років і закінчилися в 1648 році поділом церкви і держави, справжня транссрормація була б неможлива. Це підтверджують випадки Китаю та ісламського світу. У другій половині вісімнадцятого століття промислова революція відбулася в Англії, а звідти вона поширилася по інших країнах Європи і Північної Америки. Об'єднання основних економічних, соціальних, культурних, наукових і технологічних досягнень - це те, що ми називаємо промисловою революцією. Це була революція, яка змінила сільськогосподарський спосіб життя і спосіб виробництва, змусивши всі інші соціальні та політичні структури і людські відносини докорінно і безповоротно змінитися [3-4].
Поява і поширення нового способу організації виробництва послужило іскрою, що поклала початок промислової революції. Робочих збирали в одне місце для спільної роботи на одного майстра, який часто був єдиним власником засобів виробництва і товарів, які повинні були проводитися. Робочі більше не могли визначати свій робочий час і порядок виконання своєї роботи. Були поставлені завдання, визначено робочий час, розроблені і застосовані правила, встановлені і впроваджені ієрархічні відносини на робочому місці. Дохід був прив'язаний до роботи, а виживання і рівень життя стали функцією доступності роботи і здатності працівника працювати понаднормово і переносити біль виконання повторюваних, нудних завдань. Люди, які працювали на нового підприємця, часто були безземельними і безпорадними людьми, яким нічого було продавати, крім своєї праці. Через це безсилля вони, особливо в першому столітті індустріальної ери, піддавалися експлуатації та жорстокому поводженню.

Критики цього розвитку розглядали поява трущоб як злочин, умисно вчинене безсердечним капіталістичним класом. В результаті вони закликали до змін, але не погодилися 3 їх спрямуванням. Розбіжності щодо направлення змін розділили критиків за двома напрямками: одне - революційне, інше - утопічне. Але, незважаючи на кілька спроб здійснити революції і побудувати утопії, історія зробила і утопію, і революцію непрактичною і нездійсненною в довгостроковій перспективі. Історія пройшла еволюційний шлях, який привів нас туди, де ми знаходимося сьогодні.

Новостворені спільноти, які з'явились у великих промислових містах, учасниками яких були сім'ї, що жили в невеликих житлових приміщеннях, зіткнулись з такими ж проблемами. Традиції та звичаї, які раніше виконували роль соціального клею, та які забезпечували старі сільськогосподарські програми протягом великої кількості поколінь, більше не мали таку доступність та не були есрективними в сучасному промисловому середовищі. До прикладу, будинок для однієї сім'ї 3 прилягаючою фермерською територією, більше не мав вже своєї виключної економічної та соціальної ролі в оновленому індустріальному суспільстві, так як він вже не міг виконувати свої усталені завдання. Освіта молодшого покоління, виробництво одягу, переробка сільськогосподарської сировини, соціальні розваги повністю чи частково перемістились 3 меж будинка на нові інституції та 
підприємства, які були під керівництвом професійно підготовлених фрахівців. Окрім того, догляд за немічними та особами похилого віку також перейшов за межі будинку до лікарень та спеціалізованих геріатричних установ, що ще більше послабили сімейні зв'язки. Таким чином, ні племінні угрупування, ні клани не могли продовжувати своє ефрективне фрункціонування у сьогоденному індустріальному суспільстві [5-7].

У той час як плем'я являло все суспільство в племінну епоху, розширена сім'я або клан представляли одиницю суспільства в сільськогосподарську епоху. В індустріальну епоху ні плем'я, ні клан не могли пережити зміни, викликані промисловою революцією; тому вона повинна була зникнути і бути замінена ядром сім'ї як осередком суспільства.

У міру дозрівання індустріального суспільства сталася комунікаційна революція і інфрормаційна революція, які знову змінили реальність. 1990-ті роки, які засвідчили розвиток двох революцій, ознаменували початок нового перехідного періоду в історії людства. Це почалося, коли економіка почала переходити від виробництва торгованих товарів до торгується інсрормації та послуг. Наприклад, в Сполучених Штатах «зайнятість в ссрері послуг продовжувала зростати і тепер становить 80 відсотків усіх робочих місць. В кабінетах лікарів працює більше людей, ніж на автомобільних заводах, більше в пральнях і хімчистках, ніж в сталеливарні заводи [5-7].

Спільних традицій і цінностей, мов, колективного історичного досвіду і спогадів вже недостатньо для підтримки єдності і життєздатності культури, суспільства або навіть сім'ї, особливо в довгостроковій перспективі. Інтереси, спосіб життя, хобі, профресії і освіту стали більш важливими у формуванні нових спільнот і поділі старих. А оскільки так звані віртуальні спільноти можуть долати політичні кордони і соціокультурні розбіжності, вони допомагають створювати унікальну глобальну культуру з їі основними цінностями. Міграції, що перетинають політичні кордони і дискримінація меншин, розділили національні товариства на субсуспільства по соціокультурним лініям, що підриває національну єдність та ідентичність, оскільки вони послаблюють національну державу.

Глобалізація - це процес трансорормації, спрямований на інтеграцію світових економік і об'єднання всіх народів 3 їх культурою і проблемами в мережу відносин, які впливають на їхнє життя і впливають на їх умови життя і майбутнє. Як конструкція глобальної трансформації, глобалізація має унікальну інфрраструктуру, надбудову та інститути. У той час як всесвітні телекомунікаційні та інфрормаційні мережі забезпечують глобалізацію надійної інораструктурою, міжнародні закони, організації та угоди забезпечують ефективну надбудову для регулювання створення економічних співтовариств і зон вільної торгівлі. Що стосується основних інститутів глобалізації, то це Світовий банк, Міжнародний валютний фонд і Світова організація торгівлі. Однак у міру розвитку глобалізації вона нав'язує світовій спільноті промислову спеціалізацію і міжнародний поділ праці, в результаті чого країни поділяються на багатих і бідних. Адам Сміт, засновник економіки, більше 250 років тому зауважив, що масштаби ринку обмежують поділ праці. Таким чином, розширення капіталістичного ринку на всі держави призвело до міжнародного поділу праці, що відбиває порівняльні переваги його учасників. У той час як природні ресурси, населення і довкілля становили більшість економічних переваг в недавньому минулому, основні ресурси, які мають значення сьогодні, - це правильні знання і правильне ставлення.

Висновки. Як результат, ми зазначимо, що дослідження представлене у статті характеризує етапи розвитку людства і лише доводить унікальність нашої з вами цивілізації, яка пройшла складний і дуже тривалий період, який супроводжувався перешкодами і різноманітними проблемами. Наша цивілізація мала і перехідні періоди, які можна розглядати в широкому сенсі цього слова і вважати їх свого роду «розривами» в історичному процесі, які фрункціонують як майстерні для деструктивного творчості, де творчість $€$ інструментом руйнування, а руйнування - передумовою для творчості та реконструкції. Деструктивна творчість як така сама по собі покращує прояснення ситуацій, які виникають, ніж їх контроль або прогнозування результатів. У перехідні періоди відносини між інститутами і системами в суспільстві, як правило, стають хаотичними, в результаті чого старі правила і положення стають менш ефективними.

Старі теорії мислення та соціальних систем застарівають раніше, ніж розробляються нові, щоб справлятися зі зміненими ситуаціями, змушуючи людей заплутатися і часто втрачати відчуття напрямку. У такі моменти інтелектуальна творчість і активність зазвичай виходять за рамки відомого і традиційного, щоб винаходити нові способи вирішення 
всіх проблем. Така діяльність і нові ідеї, які вона зазвичай проводить, підривають традиційну мудрість і переважаючі світогляду, викликаючи появу нових способів мислення і дій, які замінюють застарілі. Кожна цивілізація створила свою власну велику культуру з декількома субкультурними відтінками, які схожі один на одного, але не ідентичні.

Колишні суспільства стають залежними від нових, майже не маючи надії на відновлення своєї свободи або незалежності. 3 кожним перехідним періодом суспільства, створені більш ранніми цивілізаціями, виявляються вимушеними визнати перевагу нової цивілізації, прийняти деякі з її інститутів, імітувати певні аспекти ії життя, прийняти залежність від неї або поступово перетворюватися в непотрібну. Історія кожної цивілізації закінчується перехідним періодом, що знаменує кінець однієї історії і початок іншої; кожна має свою логіку і динаміку і актуальна тільки для свого суспільства і часу.

\section{СПИСОК ВИКОРИСТАНИХ ДЖЕРЕЛ:}

1. Braudel, Fernand (1961) "European Expansion and Capitalism, 1450-1650". Pp. 245- 288 in Contemporary Civilization Staff of Columbia College, Columbia University, eds. Chapters in Western Civilization. New York : Columbia University Press.

2. Brenner, Robert (1998) The Economics of Global Turbulence: A Special Report on the World Economy, 1950-98. Special issue New Left Review, 229 (May/June).

3. Robinson, William I. (1996) Promoting Polyarchy. Cambribge, England: Cambridge University Press.

4. Sklair, Leslie (1991) Sociology of the Global System: Social Change in Global Perspective. Baltimore, Maryland : The Johns Hopkins University Press.

5. Wade, Robert (1996) "Globalization and its Limits: Reports on the Death of the National Economy are Greatly Exaggerated." In Suzanne Berger and Ronald Dore, eds., National Diversity and Global Capitalism. Ithaca, New York: Cornell University Press.

6. Wallerstein, Immanuel (1984) The Politics of the World-Economy: The States, the Movements, and the Civilizations. Cambridge, England : Cambridge University Press.

7. Foster, John Bellamy (1996) "Sustainable Development of What?" Capitalism, Nature, Socialism, 7:3, 129-132. 